\title{
Experimental studies on seed production of tropical grasses in Kenya. 4. The effect of fertilizer and planting density on Chloris gayana cv. Mbarara
}

\section{J. G. Boonman}

National Agricultural Research Station, Kitale, Kenya

Received: 7 March 1972

\section{Summary}

The effects of phosphate in the seed bed (0-80 $\mathrm{kg} \mathrm{P}_{2} \mathrm{O}_{5}$ per ha), nitrogen $(0-200 \mathrm{~kg} \mathrm{~N}$ ha $^{-1}$ crop $\left.^{-1}\right)$, seed rate $(0.2-1.8 \mathrm{~kg}$ Pure Germinating Seed (PGS) per ha) and row width (broadcast planting $-100 \mathrm{~cm}$ ) were studied each at five levels over four years in a central composite design.

In the establishment crop, phosphate failed to affect any yield aspect, while seed rate reduced yield of clean seed and number of heads but increased yield of dry matter significantly. Seed rate and row width did not affect yield of PGS significantly. Row width decreased yield of dry matter.

In the six post-establishment crops, nitrogen was the only factor which was important for seed yield. By applying $100 \mathrm{~kg} \mathrm{ha}^{-1} \mathrm{crop}^{-1}$ yield of PGS was on average increased more than sixfold, to $41 \mathrm{~kg} \mathrm{ha}^{-1} \mathrm{crop}^{-1}$ at a row width of $50 \mathrm{~cm}$. Yield of PGS was highest at $25 \mathrm{~cm}$ row width and $150 \mathrm{~kg} \mathrm{~N}$ per ha, but the effect of row width was not significant. Row width however increased yield of dry matter and number of heads. Increases in nitrogen and row width accelerated the onset of heading.

\section{Introduction}

In my previous paper (Boonman, 1972) it was shown that adequate nitrogen (N) and close row width (R) increased yield of Pure Germinating Seed (PGS) considerably in Setaria sphacelata cv. Nandi II. Phosphate (P) and seed rate (SR) had no significant effect in the establishment crop.

The object of the present study was to investigate the effects of the same factors on Rhodes grass, Chloris gayana cv. Mbarara. Although Rhodes grass is a stoloniferous species, the original sowing lines remain distinguishable for several years; this is particulary evident after a burn.

Mbarara Rhodes is widely grown in Kenya (Bogdan, 1969). It is early heading and a relatively good seeder (Boonman, 1971).

\section{Materials and methods}

The design, treatments and operations were the same as those described for Experiment II of my previous paper (Boonman, 1972). Both experiments ran concurrently. The 
first planting on 17 April 1968 failed. Seed was replanted without phosphate into the original lines on 17 July 1968. Samplings for tillering and heading were carried out in the first two crops. These proved to be difficult to carry out because of the dense stands and were not repeated in subsequent crops. In the 1970 crops Initial Head Emergence was estimated (IHE, 5-10 heads per $\mathrm{m}^{2}$ ).

To cope with the numerous samples for PGS testing, a quick routine method was developed. Seed samples were first cleaned sharply on a 'Brabant' clipper. Germination was tested on ordinary zinc trays in a greenhouse. During daytime, a temperature of $30^{\circ} \mathrm{C}$ or just above was maintained under the bell jars by replacing part of the water in the trays with boiling water in the morning. The greenhouse was heated with charcoal stoves when the temperature dropped below 30 . It rarely dropped much below 20 at night.

\section{Results}

Seven harvests have been taken up till 1972. At each harvest observations were carried out on tiller and head numbers, percentage heading tillers, yields of dry matter and clean seed, percentage and yield of PGS, raceme characteristics, 1000-grain weight, culm length, seed retention and lodging.

This paper is confined to reporting on important comparisons and points of difference with the previous paper (Boonman, 1972). The data for the establishment crop harvested in December 1968 are presented in Table 1, while Table 2 shows the averages of the six post-establishment crops. Table 3 gives the yields and percentages of PGS at 0 , 100 and $200 \mathrm{~kg} \mathrm{~N} \mathrm{ha}^{-1} \mathrm{crop}^{-1}$. In Table 4 the crop-to-crop variation is presented for

Table 1. Yield characteristics of the establishment crop, December 1968.

\begin{tabular}{|c|c|c|c|c|c|c|}
\hline $\begin{array}{l}\text { Seed } \\
\text { rate } \\
(\mathrm{kg} / \mathrm{ha})\end{array}$ & $\begin{array}{l}\text { Row } \\
\text { width } \\
\text { (cm) }\end{array}$ & $\begin{array}{l}\text { Yield of } \\
\text { clean seed } \\
(\mathrm{kg} / \mathrm{ha})\end{array}$ & $\begin{array}{l}\text { PGS } \\
\%\end{array}$ & $\begin{array}{l}\text { Yield of } \\
\text { PGS } \\
\text { (kg/ha) }\end{array}$ & $\begin{array}{l}\text { Yield of } \\
\text { dry matter } \\
\text { (tons/ha) }\end{array}$ & $\begin{array}{l}\text { Number } \\
\text { of heads } \\
\text { per } \mathrm{m}^{2}\end{array}$ \\
\hline 0.2 & 50 & 145 & 33.4 & 48.5 & 7.3 & 410 \\
\hline $\begin{array}{l}0.6 \\
0.6\end{array}$ & $\begin{array}{l}25 \\
75\end{array}$ & $\begin{array}{l}117 \\
143\end{array}$ & $\begin{array}{l}46.1 \\
40.1\end{array}$ & $\begin{array}{l}53.9 \\
57.3\end{array}$ & $\begin{array}{l}7.9 \\
6.9\end{array}$ & $\begin{array}{l}360 \\
350\end{array}$ \\
\hline $\begin{array}{l}1.0 \\
1.0 \\
1.0\end{array}$ & $\begin{array}{l}\text { Broadcast } \\
50 \text { (central point) } \\
100\end{array}$ & $\begin{array}{l}160 \\
125 \\
155\end{array}$ & $\begin{array}{l}45.6 \\
45.2 \\
31.0\end{array}$ & $\begin{array}{l}73.0 \\
56.5 \\
48.0\end{array}$ & $\begin{array}{l}7.3 \\
7.8 \\
6.4\end{array}$ & $\begin{array}{l}400 \\
350 \\
420\end{array}$ \\
\hline $\begin{array}{l}1.4 \\
1.4\end{array}$ & $\begin{array}{l}25 \\
75\end{array}$ & $\begin{array}{r}96 \\
125\end{array}$ & $\begin{array}{l}48.2 \\
44.3\end{array}$ & $\begin{array}{l}46.3 \\
55.4\end{array}$ & $\begin{array}{l}8.6 \\
7.3\end{array}$ & $\begin{array}{l}340 \\
340\end{array}$ \\
\hline \multirow[t]{2}{*}{1.8} & 50 & 110 & 43.6 & 48.0 & 8.3 & 310 \\
\hline & C.V. \% & 20.8 & - & 24.2 & 9.1 & 12.6 \\
\hline $\begin{array}{l}\text { Source of } \\
\text { variation }\end{array}$ & $\begin{array}{l}\text { SR } \\
\mathbf{R} \\
\mathbf{P} \\
\text { interactions }\end{array}$ & $\begin{array}{l}* \\
* \\
\text { NS } \\
\text { NS }\end{array}$ & $\underline{-}$ & $\begin{array}{l}\text { NS } \\
\text { NS } \\
\text { NS } \\
\text { NS }\end{array}$ & $\begin{array}{l}* \\
* * \\
\text { NS } \\
\text { NS }\end{array}$ & $\begin{array}{l}* \\
\text { NS } \\
\text { NS } \\
\text { NS }\end{array}$ \\
\hline
\end{tabular}

${ }^{* \mathrm{P}}<0.05 ;{ }^{* * \mathrm{P}}<0.01 ; \mathrm{NS}=$ not significant. 


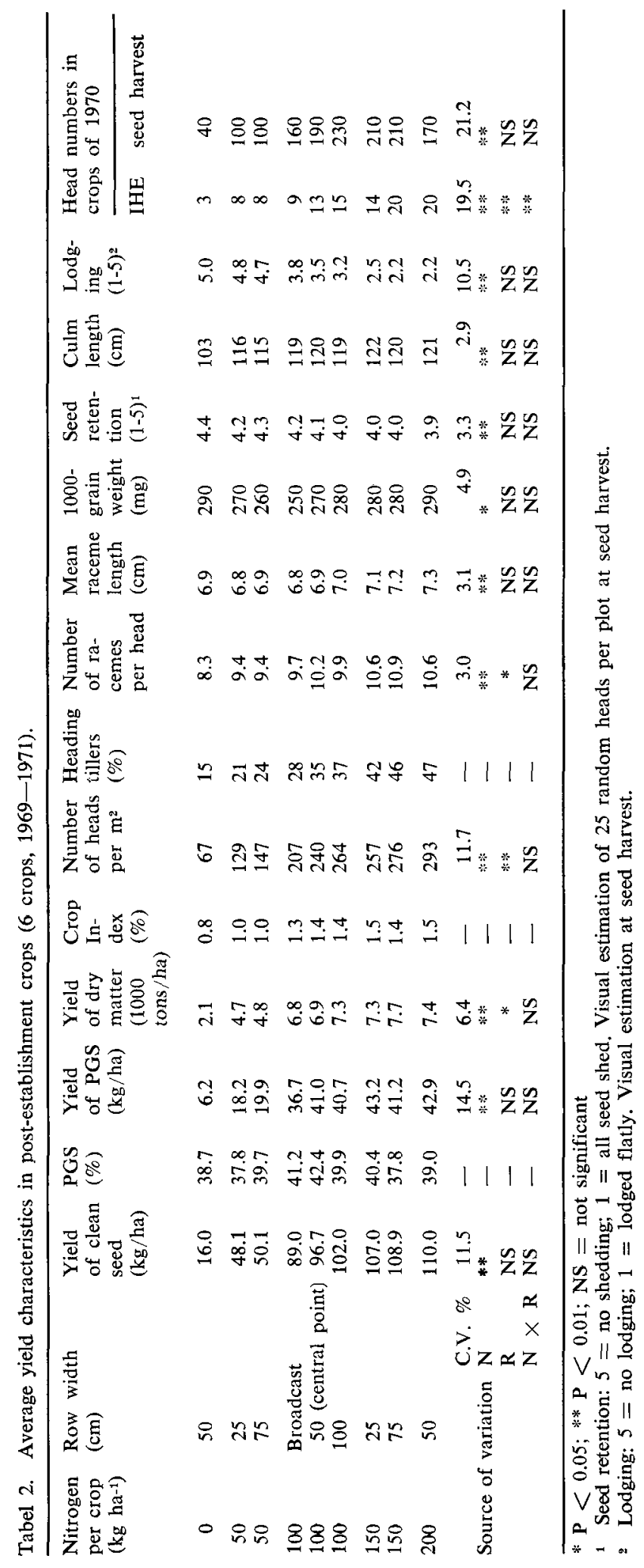


the central point of the design. Table 5 shows some raceme characteristics as observed in the second crop.

\section{Establishment crop}

The highest yield of PGS in the whole experimental period, $73 \mathrm{~kg}$ per ha, was achieved in the establishment crop with the combination of broadcast planting and medium SR (Table 1). The yield of clean seed was also highest with this treatment, but was reduced by seed rates above $1 \mathrm{~kg}$. The percentage of PGS was highest at $S_{1.4} R_{25}$, i.e. at high planting density. The same applied to yield of dry matter. Yield of PGS was not significantly affected by SR and R.

Tiller numbers were highest at $\mathbf{S R}_{0.2} \mathbf{R}_{50}$ in all samplings of the heading period. $\mathbf{R}$ had little effect but SR decreased numbers significantly except at time of seed harvest (data not presented). At this time SR decreased head numbers significantly (Table 1). $R$ and SR had no significant effect on raceme length and raceme number per head, 1000-grain weight and percentage of heading tillers while culms were significantly shorter at wide $\mathrm{R}$ (data not presented). All these variables were rather high compared with most subsequent crops (Table 4).

$P$ did not affect any aspect of yield. Hence treatment levels were not continued in the post-establishment crops.

\section{Post-establishment crops}

No effect of SR was found. $N$ emerged as the most important factor. Yield of PGS was increased more than sixfold by the application of $100 \mathrm{~kg} \mathrm{~N} \mathrm{ha}^{-1} \mathrm{crop}^{-1}$ (Table 2). Increasing $\mathrm{N}$ from 50 to $100 \mathrm{~kg}$ doubled the yields. The effect of $\mathrm{R}$ was not significant. The highest yield, $43.2 \mathrm{~kg}$, was achieved at $\mathrm{N}_{150} \mathrm{R}_{25}$. The top $\mathrm{N}$ levels increased the yield of PGS slightly. On the average they increased the yield of clean seed but tended to decrease the percentage of PGS (Table 2 and 3). $N_{200}$ outyielded $N_{100}$ in two harvests, October 1970 and November 1971, both having high yield levels (Table 3). In the absence of $\mathrm{N}$ yields were still high in the first post-establishment crop but subsequently dropped to as little as $2 \mathrm{~kg}$ per ha. The high yield obtained with $\mathrm{N}_{0}$ in July 1971 could be attributable to the increased nitrogen mineralized after the extremely dry season $1970 / 1971$.

Number of heads and number of racemes per head increased significantly with $\mathrm{N}$ and R. $\mathrm{N}$ trebled the percentage of heading tillers, $\mathrm{R}$ having a slightly positive effect. $\mathrm{N}$ increased mean raceme length and 1000-grain weight significantly (Table 2).

Table 3. Yields and percentages of Pure Germinating Seed (PGS) of post-establishment crops at row width of $50 \mathrm{~cm}$.

\begin{tabular}{|c|c|c|c|c|c|c|c|c|c|c|c|c|c|c|}
\hline \multirow[b]{2}{*}{$\begin{array}{l}\text { Nitrogen } \\
(\mathrm{kg} / \mathrm{ha})\end{array}$} & \multicolumn{7}{|c|}{ Yield of PGS (kg/ha) } & \multicolumn{7}{|c|}{ Percentage of PGS } \\
\hline & $\begin{array}{l}\text { July } \\
1969\end{array}$ & $\begin{array}{l}\text { Oct. } \\
1969\end{array}$ & $\begin{array}{l}\text { July } \\
1970\end{array}$ & $\begin{array}{l}\text { Oct. } \\
1970\end{array}$ & $\begin{array}{l}\text { July } \\
1971\end{array}$ & $\begin{array}{l}\text { Nov. } \\
1971\end{array}$ & mean & $\begin{array}{l}\text { July } \\
1969\end{array}$ & $\begin{array}{l}\text { Oct. } \\
1969\end{array}$ & $\begin{array}{l}\text { July } \\
1970\end{array}$ & $\begin{array}{l}\text { Oct. } \\
1970\end{array}$ & $\begin{array}{l}\text { July } \\
1971\end{array}$ & $\begin{array}{l}\text { Nov. } \\
1971\end{array}$ & mean \\
\hline 0 & 13 & 3 & 2 & 5 & 11 & 4 & 6.2 & 55 & 36 & 47 & 39 & 34 & 26 & 38.7 \\
\hline 100 & 34 & 42 & 27 & 32 & 51 & 60 & 41.0 & 63 & 39 & 37 & 40 & 37 & 47 & 42.4 \\
\hline 200 & 20 & 36 & 26 & 63 & 40 & 71 & 42.9 & 58 & 27 & 48 & 44 & 31 & 44 & 39.0 \\
\hline
\end{tabular}


Table 4. Crop characteristics at the central point of design.

\begin{tabular}{|c|c|c|c|c|c|c|c|}
\hline Crop characteristics & $\begin{array}{l}\text { Dec. } \\
1968\end{array}$ & $\begin{array}{l}\text { July } \\
1969\end{array}$ & $\begin{array}{l}\text { Oct. } \\
1969\end{array}$ & $\begin{array}{l}\text { July } \\
1970\end{array}$ & $\begin{array}{l}\text { Oct. } \\
1970\end{array}$ & $\begin{array}{l}\text { July } \\
1971\end{array}$ & $\begin{array}{l}\text { Nov. } \\
1971\end{array}$ \\
\hline Yield of clean seed $(\mathrm{kg} / \mathrm{ha})$ & 125 & 53 & 107 & 74 & 81 & 137 & 128 \\
\hline Percentage PGS & 45 & 63 & 39 & 37 & 40 & 37 & 47 \\
\hline Yield of PGS $(\mathrm{kg} / \mathrm{ha})$ & 57 & 34 & 42 & 27 & 32 & 51 & 60 \\
\hline Yield of dry matter (1000 tons $/ \mathrm{ha}$ ) & 7.8 & 6.5 & 8.4 & 7.9 & 7.5 & 6.7 & 4.2 \\
\hline Crop Index $(\%)$ & 1.6 & 0.8 & 1.3 & 0.9 & 1.1 & 2.1 & 3.0 \\
\hline Number of heads per $\mathrm{m}^{2}$ & 350 & 320 & 110 & 250 & 120 & 330 & 310 \\
\hline Percentage heading tillers & 51 & 38 & 20 & 36 & - & 51 & 46 \\
\hline Number of racemes per head & 11.1 & 8.2 & 10.9 & 11.5 & 10.0 & 11.1 & 9.4 \\
\hline Average raceme length $(\mathrm{cm})$ & 7.1 & 6.5 & 7.0 & 7.0 & 7.1 & 7.0 & 6.9 \\
\hline 1000-grain weight (mg) & 320 & 290 & 270 & 220 & 250 & 290 & 300 \\
\hline Seed retention $(1-5 ; 5=$ no shedding $)$ & - & - & 4.5 & 3.9 & 4.7 & 4.1 & 3.3 \\
\hline Culm length $(\mathrm{cm})$ & 130 & 129 & 128 & 123 & - & - & 100 \\
\hline Lodging $(1-5 ; 5=$ no lodging) & - & 3.4 & 2.0 & 4.9 & 3.0 & 4.1 & 3.5 \\
\hline
\end{tabular}

The data on seed retention indicate that $\mathrm{N}$ increased shedding. This was undoubtedly so because $\mathrm{N}$ accelerated IHE (Table 2). $\mathrm{R}$ did the same but the effect was less pronounced. In the experiments on Nandi previously described (Boonman, 1972) numbers at IHE were highest at medium $\mathrm{N}$.

In the crop of July 1969 tillers were counted at 3-4 weekly intervals. A significant response to $\mathrm{R}$ was found at the first sampling only, when tiller numbers were highest at $R_{100}$ (data not presented). However $R$ decreased tiller numbers in the Nandi experiments of my previous paper (Boonman, 1972). Nandi produced more tillers than Mbarara and tillers were fewer but heavier in the establishment crop.

Table 5 shows the average raceme characteristics of the same crop for various dates of sampling. Values were higher on 17 June than at IHE and at seed harvest. This is in line with the findings on head length in Nandi as described in the previous paper.

$\mathrm{N}$ and $\mathrm{R}$ increased the yield of dry matter significantly (Table 2). Yields were low in the fourth year, 1971 (Table 4). $\mathrm{N}$ increased culm length and lodging significantly (Table 2) while $\mathrm{R}$ tended to increase lodging also, but the effect was not significant. $\mathrm{N}$ nearly doubled the Crop Index, $R$ having no effect. An unusually high Crop Index, $3.0 \%$, was observed for the November 1971 harvest (Table 4). High yield of clean seed was accompanied by a low yield of dry matter. This crop was also characterized by a low culm length.

Table 5. Average raceme characteristics, seed crop July 1969.

\begin{tabular}{lll}
\hline Date & $\begin{array}{l}\text { Number of racemes } \\
\text { per head }\end{array}$ & $\begin{array}{l}\text { Length per } \\
\text { raceme }(\mathrm{cm})\end{array}$ \\
& 9.1 & 7.0 \\
27 May (IHE) & 9.9 & 7.3 \\
17 June & 8.3 & 6.7 \\
10 July (seed harvest) & \\
\hline
\end{tabular}




\section{Discussion}

The most striking difference between the above results and those of the experiments on Nandi described previously (Boonman, 1972) was the observation that yield and percentage of PGS were about twice as high in Mbarara (Table 2, 3 and 4). Yields did not vary as much from crop to crop. Yields of dry matter were lower and tended to go down from the fourth crop onwards whereas seed yields did not show this trend. If the decline in yield of dry matter mirrors the lack of persistency that Mbarara normally displays in contrast with Nandi, this may be due to the higher percentage of heading tillers and lower tillers numbers found in this experiment compared with the Nandi experiments. It is, however, worth noting that yields of PGS were highest in the last crop (Table 3 and 4).

The response to $\mathrm{N}, \mathrm{R}, \mathrm{SR}$ and $\mathrm{P}$ was basically the same as found before (Boonman, 1972).

$\mathrm{N}$ was the most important factor in growth of the post-establishment crops. Whereas high $\mathrm{N}$ decreased yield of PGS considerably in Nandi, $\mathrm{N}_{150}$ and $\mathrm{N}_{200}$ continued to increase yield in Mbarara, although percentage of PGS was slightly reduced. The optimum level is about $100 \mathrm{~kg} \mathrm{~N}^{\mathrm{Na}} \mathrm{h}^{-1} \mathrm{crop}^{-1}$.

The effect of $R$ on yield of PGS was not significant but close $R$ outyielded wide $R$ at high $\mathbf{N}$ (Table 2). This was mainly due to the positive effect of close $R$ on the percentage PGS since yield of clean seed tended to be higher at wide $R$.

In the establishment crop broadcast planting produced the highest yield. The highest average yield of PGS in the post-establishment crops was achieved at $N_{150} R_{25}$ (Table 2). However yield of clean seed, head numbers and other heading characteristics were actually lower at this treatment than at $\mathbf{N}_{200} R_{50}$ and $\mathbf{N}_{150} R_{75}$, which came second and third in yield of PGS. The higher yield of PGS in the first treatment, $\mathbf{N}_{150} \mathbf{R}_{\mathbf{2 5}}$, was brought about by a proportionally higher percentage of PGS. As discussed before (Boonman, 1972) this increased percentage of PGS is most likely due to the more concentrated heading in this treatment combination since $N$ and $R$ accelerated IHE (Table 2) and possibly also due to a more even maturation in short racemes.

As $\mathrm{N}$ accelerated heading it also increased shedding (Table 2). This was unexpected since heads in high $\mathrm{N}$ plots usually look darker at harvesting time than heads in low $\mathrm{N}$ plots.

Despite a range of 0.2-1.8 kg PGS per ha, SR had no significant effect on yield of PGS in the establishment crop nor, as could be expected, in subsequent seed crops. There was a tendency for yields to be reduced by SR above $1 \mathrm{~kg}$ as in the Nandi experiments (Boonman, 1972). Rates below $1 \mathrm{~kg}$ appeared less harmful than those above. There was no $R \times S R$ interaction. Thus $S R$ does not need to be increased to suit close R. Assuming 50\% failure and a 1000-grain weight of $250 \mathrm{mg}, 1 \mathrm{~kg}$ PGS when planted in $50-\mathrm{cm}$ rows still produces one seedling per $\mathrm{cm}$ row length. Stiff competition therefore ensues from high seed rates, particularly in wide rows. Seed take, however, is often determined more by environmental conditions than by seed rate alone.

It is important to note that density had a greater effect on dry matter yield and head number than on yield of PGS, both in the establishment crop and thereafter.

$\mathbf{P}$ was not found to have any effect on yields in the establishment crop (Table 1). Dougall (1954) and Holme and Sherwood (1954) have shown that the effect of P on grasses in the Kenya Highlands was limited, except when applied in the seed-bed to promote rapid establishment. In trials carried out by me on the red sandy clays derived from the basement complex around Kitale, grass establishment was promoted in some cases and 
reduced in others by $P$. The negative effect of $P$ was probably due to scorching of the seed after planting. In some trials no effect was noted. In another trial six consecutive crops were harvested for seed with complete removal of herbage following a single top dressing with rates varying from $0-80 \mathrm{~kg} \mathrm{P}_{2} \mathrm{O}_{5}$ per ha. No response to $\mathrm{P}$ was found in any of the harvests but yields of seed and herbage were normal (Boonman, unpublished data). These trials were carried out on soils that had received $P$ in the past at varying amounts. It is difficult to base the need for $\mathbf{P}$ on soil analysis because even in maize which responds very well to $P$, little correlation exists between soil analysis data and yield response to applied P (Osborne and Allan, 1971). Grass seed is seldom the first crop in an arable break and normally follows maize which is liberally supplied with $P$. It seems advisable to confine the heavy dressings of $P$ to the cereal break and only to apply a little $\mathbf{P}$ in the seed-bed of the grass seed crop.

\section{References}

Bogdan, A. V., 1969. Rhodes grass. (Review article). Herb. Abstr. 39: 1-13.

Boonman, J. G., 1971. Experimental studies on seed production of tropical grasses in Kenya. 2. Tillering and heading in seed crops of eight grasses. Neth. J. agric. Sci. 19: 237-249.

Boonman, J. G., 1972. Experimental studies on seed production of tropical grasses in Kenya. 3. The effect of nitrogen and row width on seed crops of Setaria sphacelata cv. Nandi II. Neth. J. agric. Sci. 20: 22-34.

Dougall, H. W., 1954. Fertilizer experiments on grassland in the Kenya Highlands. E. afr. agric. J. 19: $171-178$.

Holme, R. V. \& E. G. P. Sherwood, 1954. The fertilizer requirements of the Kenya Highlands. Colonial Research Studies, 12. Her Majesty's Stationery Office.

Osborne, J. F. \& A. Y. Allan, 1971. Record of Research. East Africen Agricultural and Forestry Research Organization. (In press.) 